\title{
Relation Between Pituitary Responsiveness to Thyrotropin Releasing Hormone and Serum Thyroid Hormones in Hyperthyroidism
}

\author{
Mizuo AZUKIZAWA, KiYoshi MIYAI, YUICHI KUMAHARA, \\ AND TOSHIHIDE YAMAMOTO* \\ Central Laboratory for Clinical Investigation, \\ Osaka University Medical School, Dojima Fukushima-ku \\ Osaka and Center for Adult Diseases, * Osaka 530
}

\begin{abstract}
Synopsis
Seventy-five TRH tests were carried out in 61 subjects with hyperthyroidism before and in the course of treatment; the results were correlated with serum $T_{4}$ and $T_{3}$ concentrations. In certain subjects, $T_{3}$ suppression tests were done along with the TRH test. All subjects with elevated $\mathrm{T}_{4}$ and $\mathrm{T}_{3}$ (group 1) did not show a TSH response to TRH. Eleven out of 13 subjects with normal $\mathrm{T}_{4}$ and elevated $\mathrm{T}_{3}$ (group 2 ) did not show TSH response. In 22 subjects with normal $T_{4}$ and $T_{3}$ (group 3), 40.9\% (9/22) did respond and $59.1 \%(13 /$ 22) did not respond to TRH. In 7 subjects with low $T_{4}$ and/or $T_{3}$ (group 4 ), 4 did not respond and 3 did respond to $T R H$. In each group, there were no significant differences in age and sex of the subjects, mode of therapy, serum thyroid hormones $\left(T_{4}, T_{3}\right)$ and $B M R$ between responders and non-responders to TRH. Sixteen subjects underwent $T_{3}$ suppression tests. Twelve subjects with no or low TSH response to TRH did not show suppression, while all 4 subjects with normal or exaggerated TSH response showed suppression. The results indicate that serum thyroid hormone levels are not the sole determinant of the TSH response to TRH and confirm that the suppressibility of the thyroid gland by $\mathrm{T}_{3}$ appears to require the presence of sufficient TSH secretion from the pituitary. Several mechanisms of variable TSH response to TRH in the course of treatment of hyperthyroidism were discussed.
\end{abstract}

Serum thyrotropic hormone (TSH) concentration rises after the administration of thyrotropin-releasing hormone (TRH) to hypothyroid and euthyroid subjects. In contrast, patients with untreated hyperthyroidism do not show a TSH response to TRH, presumably resulting from suppression of the pituitary thyrotropic cells by increased thyroid hormones in blood (Haigler et al., 1971; Ormston et al., 1971).

The TSH response to TRH in patients rendered clinically euthyroid by therapy remains controversial. Shenkman et al. and Ormston et al. ascribed failure of TSH response to TRH in certain subjects to elevated serum triiodothyronine $\left(T_{3}\right)$ (Shenkman et

\footnotetext{
Received for publication May 8, 1974.
}

al., 1973; Ormston et al., 1971). Two patients described by Lawton et al. showed lack of TSH response to TRH together with nonsuppressibility of thyroid function after $T_{3}$ in the presence of normal serum total thyroxine $\left(T_{4}\right)$, free $T_{4}$, and total $T_{3}$ concentration. (Lawton et al., 1971) One subject reported by Hershman et al. showed a small TSH response to TRH in the face of elevated serum $T_{4}$. (Hershman and Pittman, 1970).

In the present report, the incidence of TSH unresponsiveness to TRH was sought in a larger number of subjects with treated and untreated hyperthyroidism and the relation between TSH and serum thyroid hormones was investigated. Results of $T_{3}$ suppression tests obtained in certain subjects were correlated with those of TSH response to TRH as well. 


\section{Materials and Methods}

Sixty-one subjects were included in the study. The diagnosis of diffuse toxic goiter was made by clinical criteria. Patients were thyrotroxic, under partial control, euthyroid or hypothyroid at the time of study. Five subjects were diagnosed as 'euthyroid Graves' disease" at the time of TRH tests. Their clinical data are given in the footnotes of Tables 2 and 3 . In 12 subjects, TSH response to TRH was estimated more than once during the course of the treatment: 10 subjects were tested twice, one subject 4 times, one subject 6 times. After blood sample was drawn, $500 \mu \mathrm{g}$ (or 2,000 $\mu \mathrm{g}$ when specified) of TRH was administered intravenously. Three additional blood samples were drawn after 30, 60 and $120 \mathrm{~min}$. Serum TSH was measured by double antibody radioimmunoassay modified to retain high sensitivity as described by Patel et al. (Patel et al., 1971). The assay was sensitive enough to detect TSH as low as $0.5 \mu \mathrm{U} / \mathrm{m} l$ and to distinguish difference of $0.5 \mu \mathrm{U}$ in the range between 0.5 and $10 \mu \mathrm{U} / \mathrm{ml}$. Serum T4 was measured by competitive protein binding assay, using Res-o-mat T4 kit (Mallinckrodt Co.). The results were expressed as $\mathrm{T}_{4}$-iodine $\left(\mathrm{T}_{4}-\mathrm{I}\right) \mu \mathrm{g} / 100 \mathrm{ml}$. Serum $\mathrm{T}_{3}$ was measured by radioimmunoassay described by Chopra et al. (Chopra et al., 1972). The antibody against $T_{3}$ was raised in rabbit according to Gharib et al. (Charib et al., 1971). The crossreactivity with $\mathrm{T}_{4}$ of the antibody was $0.01 \% . T_{3}$ resine sponge uptake $\left(\mathrm{RT}_{3} \mathrm{U}\right)$ was measured using Triosorb test kit (Dainabot Laboratory). Free thyroxine index ( $\mathrm{FT}_{4}$ index) was calculated according to the formula described by Hamada et al., i.e.,

$$
\begin{gathered}
\mathrm{FT}_{4} \text { index }=\frac{\mathrm{T}_{4}-\mathrm{I} \times \mathrm{RT}_{3} \mathrm{U}}{1-0.6 \times \mathrm{RT}_{3} \mathrm{U}} \\
\quad \text { (Hamada } \text { et al., 1970) }
\end{gathered}
$$

$\mathrm{T}_{3}$ suppression tests were performed as described by Werner et al. (Werner and Spooner, 1955). Lack of suppression after administration of $75 \mu \mathrm{g} \mathrm{T}_{3}$ for 8 days was defined as uptake more than $36 \%$ of the initial uptake.

\section{Results}

Seventy-five TRH tests with $500 \mu \mathrm{g}$ TRH were carried out in 61 subjects. They were divided into 4 groups according to serum $T_{4}$ and $\mathrm{T}_{3}$ levels at the time of TRH tests. Group 1 consisted of 33 subjects, whose serum $T_{4}$ and $T_{3}$ were elevated; Group 2, 13 subjects with normal $\mathrm{T}_{4}$ and elevated $\mathrm{T}_{3}$; Group 3, 22 subjects with normal $\mathrm{T}_{4}$ and $\mathrm{T}_{3}$; Group 4, 7 subjects with reduced $\mathrm{T}_{4}$ and/or $\mathrm{T}_{3}$. Herein, normal ranges of $T_{4}, T_{3}$ and $\mathrm{RT}_{3} \mathrm{U}$ were defined as $3.0-7.2 \mu \mathrm{g} / 100 \mathrm{ml}\left(\mathrm{T}_{4}-\mathrm{I}\right)$, 90-190 ng/100 ml $\left(\mathrm{T}_{3}\right)$ and $26-39 \%\left(\mathrm{RT}_{3} \mathrm{U}\right)$, based on tests of 40 euthyroid hospital employees. Serum TSH at $30 \mathrm{~min}$ after $500 \mu \mathrm{g}$ TRH i.v. administration ranges between 10 and $40 \mu \mathrm{U} / \mathrm{m} l$ in normal subjects (Kumahara et al., 1971). When more than one TRH test was carried out in a single subject in the course of therapy, results of the first TRH test were cited to avoid repetition of the same case in one group.

All subjects in group 1 failed to respond to TRH. Eleven out of 13 subjects in group 2 failed to respond to TRH while two showed normal response (Table 1). In group 3, variable TSH responses to TRH were observed: 13 subjects showed low or no response and 9 normal or supranormal responses (Table 2). When comparisons were made of age, $\mathrm{T}_{4}, \mathrm{FT}_{4}$-index, $\mathrm{T}_{3}, \mathrm{BMR}$ and modes of therapy between responders and non-responders, no differences were observed. Variable TSH response to TRH was noted in group 4 as well: 4 subjects showed no response and 3 supernormal responses. Here again, no obvious differences were observed in serum thyroid hormones (Table 3). Without exception, subjects who failed to respond to TRH always had low baseline TSH, i.e., less than $0.5 \mu \mathrm{U} / \mathrm{m} l$. As illustrated in typical cases, variable responses were observed during the course of therapy when studied repeatedly (Figs. 1 and 2).

No response or subnormal response was noted during thyrotoxic and euthyroid phases. During the hypothyroid phase, however, the responses were supranormal. Five subjects were challenged with $2,000 \mu \mathrm{g}$ as well as $500 \mu \mathrm{g}$ TRH. TSH responses to $2,000 \mu \mathrm{g}$ TRH were no greater than those after $500 \mu \mathrm{g} \mathrm{TRH}$ (Table 4). Two subjects in group 2 underwent $\mathrm{T}_{3}$ suppression tests. All failed to show suppression (Table 1). Twelve subjects in group 
Table 1. Clinical data and TSH response of subjects with normal $\mathrm{T}_{4}$ and elevated $\mathrm{T}_{3}$ (Group 2)

\begin{tabular}{|c|c|c|c|c|c|c|c|c|c|c|c|}
\hline \multirow[t]{2}{*}{ Subjects } & \multirow[t]{2}{*}{ Age } & \multirow[t]{2}{*}{ Sex } & \multicolumn{2}{|c|}{$\begin{array}{c}\text { TSH-response } \\
\text { to TRH } \\
(\mu \mathrm{U} / \mathrm{m} l)\end{array}$} & \multirow{2}{*}{$\begin{array}{c}\mathrm{T}_{4}-\mathrm{I} \\
(\mu \mathrm{g} / 100 \\
\mathrm{m} l)\end{array}$} & \multirow[t]{2}{*}{$\underset{(\%)}{\mathrm{RT}_{3} \mathrm{U}}$} & \multirow[t]{2}{*}{$\begin{array}{c}\mathrm{FT}_{4} \\
\text { Index }\end{array}$} & \multirow{2}{*}{$\begin{array}{c}\mathrm{T}_{3} \\
(\mathrm{ng} / 100 \\
\mathrm{m} l)\end{array}$} & \multirow[t]{2}{*}{$\underset{(\%)}{\text { BMR }}$} & \multirow{2}{*}{$\begin{array}{l}\mathrm{T}_{3^{-}} \\
\text {suppres- } \\
\text { sion } \\
\text { test* }\end{array}$} & \multirow[t]{2}{*}{ Therapy** } \\
\hline & & & 0 & $30 \mathrm{~min}$ & & & & & & & \\
\hline
\end{tabular}

\begin{tabular}{|c|c|c|c|c|c|c|c|c|c|c|c|}
\hline \multicolumn{12}{|c|}{ non or low responder } \\
\hline I. I. & 39 & $\mathbf{M}$ & $<0.5$ & $<0.5$ & 7.2 & 41 & 3.92 & 460 & +19 & & MMI \\
\hline Y. H. & 37 & $F$ & $<0.5$ & $<0.5$ & 5.6 & 38 & 2.76 & 330 & +16 & & PTU \\
\hline S. F. & 35 & $\mathrm{~F}$ & $<0.5$ & $<0.5$ & 5.7 & 31 & 2.17 & 275 & +12 & & untreated \\
\hline T. O. & 21 & $\mathrm{~F}$ & $<0.5$ & $<0.5$ & 5.5 & 33 & 2.26 & 263 & & & MMI \\
\hline U. T. & 23 & $\mathrm{~F}$ & $<0.5$ & $<0.5$ & 6.7 & 30 & 2.45 & 254 & +33 & - & untreated \\
\hline K. K. & 39 & $\mathrm{~F}$ & 0.5 & 0.7 & 5.3 & 28 & 1.78 & 250 & +31 & & untreated \\
\hline H. S. & 24 & $\mathbf{M}$ & $<0.5$ & $<0.5$ & 5.7 & 29 & 2.00 & 230 & -13 & - & MMI \\
\hline M. F. & 18 & $\mathrm{~F}$ & $<0.5$ & $<0.5$ & 4.0 & 27 & 1.29 & 218 & +9 & & MMI \\
\hline A. Y. & 28 & $\mathrm{~F}$ & $<0.5$ & $<0.5$ & 5.0 & 25 & 1.47 & 200 & +6 & & MMI \\
\hline A. M. & 18 & $\mathrm{~F}$ & $<0.5$ & $<0.5$ & 3.6 & 29 & 1.26 & 195 & +3 & & MMI \\
\hline T. Ok & 11 & F & 1.3 & 5.8 & 5.5 & 31 & 2.09 & 192 & -9 & & MMI \\
\hline Mean & 31.6 & & & & 5.76 & 30.8 & 2.22 & 276.5 & +12.9 & & \\
\hline$\pm \mathrm{SEM}$ & \pm 4.0 & & & & \pm 0.33 & \pm 1.2 & \pm 0.20 & \pm 22.9 & \pm 4.6 & & \\
\hline \multicolumn{12}{|c|}{ Normal responder } \\
\hline Y. Y. & 20 & $\mathrm{~F}$ & 1.8 & 16.5 & 5.5 & 28 & 1.85 & 212 & +14 & & Surgery \\
\hline T. T. & 23 & F & 1.8 & 12.0 & 6.5 & 31 & 2.48 & 203 & +4 & & MMI \\
\hline Mean & 22 & & & & 6.0 & 29.5 & 2.17 & 207.5 & +9.0 & & \\
\hline
\end{tabular}

*_: non-suppressible $\quad * * \mathrm{MMI}: 1$-methyl-2-mercaptoimidazole

PTU : 6-propyl-2-thiouracil

3 had $\mathrm{T}_{3}$ suppression tests. There was normal suppression in 4 subjects, whose TSH responses to TRH were either normal or supranormal. On the other hand, 8 subjects who failed to show suppression to $T_{3}$ had no or subnormal TSH response to TRH (Table 2).

\section{Discussion}

All subjects in group 1 showed no TSH response to TRH. Eleven out of 13 subjects in group 2 did not show TSH response to TRH. These results were comparable with others (Haigler et al., 1971; Ormston et al., 1971; Shenkman et al., 1973). In contrast to previous reports, however, 2 subjects in group 2 , with supranormal serum $T_{3}$ concentration showed TSH response to TRH and $59.1 \%$ (13/22 cases) of group 3 with normal serum
T3 concentration did not show TSH response. Moreover, 4 out of 7 subjects with reduced $\mathrm{T}_{4}$ and/or $\mathrm{T}_{3}$ (group 4) did not show TSH response to TRH.

The present radioimmunoassay of serum TSH as described earlier was highly sensitive. Therefore, the difference between positive TSH response and lack of response represents suppression of pituitary TSH secretion and is not an artifact resulting from insensitive radioimmunoassay of TSH. It is unlikely that the pituitary of TRH unresponsive subjects is irreversibly altered. Subjects unresponsive to TRH at one time became capable of responding to a second TRH test when their serum $\mathrm{T}_{4}$ and $\mathrm{T}_{3}$ were further reduced. The destruction of TRH was accelerated when it was incubated in plasma obtained from hypophysectomized rats receiving $T_{3}$ (Redding and Schally, 1969). Lack of TSH re- 
Table 2. Clinical data and TSH response of subjects with normal $\mathrm{T}_{4}$ and $\mathrm{T}_{3}$ (Group 3)

\begin{tabular}{|c|c|c|c|c|c|c|c|c|c|c|c|}
\hline \multirow[t]{2}{*}{ Subjects } & \multirow[t]{2}{*}{ Age } & \multirow[t]{2}{*}{ Sex } & \multicolumn{2}{|c|}{$\begin{array}{c}\text { TSH response } \\
\text { to TRH } \\
(\mu \mathrm{U} / \mathrm{m} l)\end{array}$} & \multirow{2}{*}{$\begin{array}{c}\mathrm{T}_{4-\mathrm{I}} \\
(\mu \mathrm{g} / 100 \\
\mathrm{m} l)\end{array}$} & \multirow{2}{*}{$\underset{(\%)}{\mathrm{RT}_{3} \mathrm{U}}$} & \multirow{2}{*}{$\begin{array}{c}\mathrm{FT}_{4} \\
\text { Index }\end{array}$} & \multirow{2}{*}{$\begin{array}{c}\mathrm{T}_{3} \\
(\mathrm{ng} / 100 \\
\mathrm{m} l)\end{array}$} & \multirow{2}{*}{$\underset{(\%)}{\text { BMR }}$} & \multirow{2}{*}{$\begin{array}{c}\mathrm{T}_{3^{-}} \\
\text {suppres- } \\
\text { sion } \\
\text { test }^{(1)}\end{array}$} & \multirow[t]{2}{*}{ Therapy ${ }^{(2)}$} \\
\hline & & & 0 & $30 \mathrm{~min}$ & & & & & & & \\
\hline \multicolumn{12}{|c|}{ non or low responder } \\
\hline K. N. & 39 & $\mathrm{~F}$ & $<0.5$ & 1.6 & 6.5 & 38 & 3.20 & 190 & +50 & & Untreated $^{(3)}$ \\
\hline M. K. & 36 & M & 0.5 & $<0.5$ & 5.0 & 32 & 1.98 & 190 & -7 & - & Untreated $^{(4)}$ \\
\hline K. M. & 20 & $\mathrm{~F}$ & $<0.5$ & $<0.5$ & 6.3 & 38 & 3.10 & 178 & +12 & - & Untreated $^{(5)}$ \\
\hline T. Og & 24 & $\mathbf{M}$ & $<0.5$ & $<0.5$ & 5.4 & 30 & 1.98 & 135 & & & MMI \\
\hline K. Y. & 27 & $\mathrm{~F}$ & $<0.5$ & $<0.5$ & 6.1 & 26 & 1.88 & 170 & +9 & - & Surgery \\
\hline T. F. & 23 & $\mathrm{~F}$ & $<0.5$ & $<0.5$ & 5.7 & 31 & 2.17 & 168 & +5 & & PTU \\
\hline Ky N. & 40 & $\mathrm{~F}$ & $<0.5$ & $<0.5$ & 4.6 & 30 & 1.68 & 155 & +21 & & $\mathrm{RI}$ and $\mathrm{MMI}$ \\
\hline M. D. & 36 & $\mathbf{F}$ & $<0.5$ & 0.6 & 5.9 & 25 & 1.74 & 146 & +3 & - & Surgery \\
\hline Y.T. & 16 & $\mathbf{M}$ & 0.7 & 0.7 & 5.7 & 30 & 2.09 & 127 & +1 & - & MMI \\
\hline I. I. & 39 & $\mathbf{M}$ & $<0.5$ & $<0.5$ & 3.0 & 27 & 0.97 & 123 & +1 & - & MMI \\
\hline F. A. & 25 & F & 0.7 & 2.1 & 5.9 & 30 & 2.16 & 141 & +11 & - & Surgery \\
\hline $\mathrm{Ka} \mathrm{N}$. & 36 & $\mathrm{~F}$ & 0.8 & 6.8 & 4.3 & 27 & 1.39 & 122 & +30 & - & PTU \\
\hline T. O. & 21 & $\mathrm{~F}$ & 1.2 & 6.3 & 4.6 & 24 & 1.29 & 130 & +7 & & MMI \\
\hline Mean & 29.4 & & & & 5.26 & 29.8 & 1.97 & 151.9 & +11.9 & & \\
\hline \pm SEM & \pm 2.3 & & & & \pm 0.27 & \pm 1.2 & \pm 0.17 & \pm 6.6 & \pm 4.3 & & \\
\hline \multicolumn{12}{|c|}{ normal or supranormal responder } \\
\hline M. Y. & 23 & $\mathrm{~F}$ & 1.3 & 19 & 6.7 & 27 & 2.16 & 176 & +5 & & MMI \\
\hline M. N. & 20 & $\mathrm{~F}$ & 2.8 & 24 & 5.4 & 24 & 1.51 & 168 & +9 & + & Surgery \\
\hline Ak $M$. & 27 & $\mathrm{~F}$ & 2.5 & 40 & 5.9 & 23 & 1.57 & 165 & -10 & + & Surgery \\
\hline Y.S. & 40 & M & 1.7 & 23 & 5.6 & 26 & 1.73 & 153 & -5 & & Untreated $^{(6)}$ \\
\hline Y. M. & 23 & $\mathrm{~F}$ & 3.0 & 28 & 6.1 & 25 & 1.79 & 145 & +14 & & Surgery \\
\hline M. H. & 24 & $\mathbf{M}$ & 2.2 & 27 & 4.2 & 35 & 1.86 & 186 & -8 & & Surgery \\
\hline N. A. & 22 & $\mathrm{~F}$ & 1.4 & 19 & 5.3 & 27 & 1.71 & 127 & +6 & + & Surgery \\
\hline M. Ko & 33 & $\mathbf{M}$ & 2.5 & 35 & 6.7 & 30 & 2.45 & 95 & & & MMI \\
\hline S. Y. & 44 & $\mathrm{~F}$ & 7.8 & 103 & 5.4 & 25 & 1.59 & 151 & -9 & + & MMI \\
\hline Mean & 27.4 & & & & 5.52 & 26.3 & 1.73 & 149.1 & +0.3 & & \\
\hline$\pm \mathrm{SEM}$ & \pm 2.6 & & & & \pm 0.28 & \pm 1.2 & \pm 0.12 & \pm 8.2 & \pm 2.74 & & \\
\hline
\end{tabular}

(1) + : suppressible $\quad-$ : non suppressible

(2) MMI: 1-methyl-2-mercaptoimidazole PTU: 6-propyl-2-thiouracil RI: radioiodine

(3) previously $\mathrm{T}_{4} 8.3 \mu \mathrm{g} / 100 \mathrm{ml}$; now clinically euthyroid without therapy

(4) previously $\mathrm{PBI} 13.6 \mu \mathrm{g} / \mathrm{d} l, \mathrm{RT}_{3} \mathrm{U} 43 \% \mathrm{BMR}+38 \%$ : now clinically euthyroid without therapy

(5) exophthalmos, and non suppressible by $T_{3}$ suppression test

(6) exophthalmos, LATS (+), TRC (+) and histologically Graves' disease with Hashimoto's disease

sponse to TRH seen in the present study, however, is hardly explained by the accelerated destruction of injected TRH because of failure of an augmented dose $(2,000 \mu \mathrm{g})$ to elecit positive response.

Age and sex were similarly distributed in subjects with positive TSH response and those without the response in groups 2, 3 and 4.
The modes of therapy employed (medical, surgical and radio-thyroidectomy) were similar between TRH responders and non-responders. No significant differences in serum $\mathrm{T}_{4}, \mathrm{~T}_{3}, \mathrm{RT}_{3} \mathrm{U}, \mathrm{FT}_{4}$ index and $\mathrm{BMR}$ were observed between TRH responders and nonresponders in groups 2, 3 and 4. As free $T_{4}$ fraction is normalized after resumption of 
Table 3. Clinical data and TSH response of subjects with low $T_{4}$ and/or $T_{3}$ (Group 4)

\begin{tabular}{|c|c|c|c|c|c|c|c|c|c|c|}
\hline \multirow{2}{*}{ Subjects } & \multirow[t]{2}{*}{ Age } & \multirow[t]{2}{*}{ Sex } & \multicolumn{2}{|c|}{$\begin{array}{c}\text { TSH-response } \\
\text { to TRH } \\
(\mu \mathrm{U} / \mathrm{m} l)\end{array}$} & \multirow{2}{*}{$\begin{array}{c}\mathbf{T}_{4-\mathbf{I}} \\
(\mu \mathrm{g} / 100 \\
\mathrm{m} l)\end{array}$} & \multirow{2}{*}{$\begin{array}{c}\mathrm{RT}_{3} \mathrm{U} \\
(\%)\end{array}$} & \multirow[t]{2}{*}{$\begin{array}{c}\mathrm{FT}_{4} \\
\text { Index }\end{array}$} & \multirow[t]{2}{*}{$\frac{\mathrm{T}_{3}}{(\mathrm{ng} / 100 \mathrm{~m} l)}$} & \multirow{2}{*}{$\underset{(\%)}{\text { BMR }}$} & \multirow[t]{2}{*}{ Therapy* } \\
\hline & & & 0 & $30 \mathrm{~min}$ & & & & & & \\
\hline \multicolumn{11}{|c|}{ non-responder } \\
\hline F. Y. & 24 & $\mathrm{~F}$ & $<0.5$ & $<0.5$ & 2.0 & 26 & 0.62 & 107 & +7 & MMI \\
\hline M.M. & 53 & $\mathbf{M}$ & $<0.5$ & $<0.5$ & 1.4 & 23 & 0.37 & 98 & +15 & MMI \\
\hline D. A. & 47 & M & $<0.5$ & $<0.5$ & 3.4 & 39 & 1.73 & 86 & -3 & MMI \\
\hline H. N. & 28 & $\mathbf{M}$ & $<0.5$ & $<0.5$ & 6.9 & 33 & 2.84 & 84 & +14 & Untreated** \\
\hline Mean & 38 & & & & 3.4 & 30.3 & 1.39 & 93.8 & +8.3 & \\
\hline \multicolumn{11}{|c|}{ supranormal responder } \\
\hline I. I. & 39 & $\mathbf{M}$ & 31 & 84 & 1.1 & 23 & 0.29 & 95 & & MMI \\
\hline K.N. & 43 & $\mathbf{F}$ & 113 & 205 & 0.6 & 27 & 0.19 & 73 & & MMI \\
\hline F. F. & 62 & $\mathrm{~F}$ & 110 & 174 & 0.6 & 23 & 0.16 & 50 & -7 & MMI \\
\hline Mean & 48 & & & & 0.76 & 24.3 & 0.21 & 72.7 & & \\
\hline
\end{tabular}

* MMI: 1-methyl-2-mercaptoimidazole PTU: 6-propyl-2-thiouracil

** Previously, non suppressible by $\mathrm{T}_{3}$ suppression test, BMR $+34 \%$ $\mathrm{T}_{4}-\mathrm{I} 9.8 \mu \mathrm{g} / 100 \mathrm{ml}, \mathrm{RT}_{3} \mathrm{U} 33 \%$; now clinically euthyroid without therapy

euthyroid state as shown by Braverman et al., free $T_{4}$ or $T_{3}$, even if measured, there seems to be no difference between TRH responders and non-responders in groups 3 and 4 (Braverman et al., 1968).

The present study showed the following: (1) A few subjects showed TSH response to TRH while their serum $T_{3}$ was still elevated. (2) more than half of the patients whose serum $T_{4}$ and $T_{3}$ was normal or reduced, had no $\mathrm{TSH}$ response to $\mathrm{TRH}$, (3) the difference of TSH response to TRH could not be ascribed to the differences in age, sex, mode of treatment, and usual clinical parameters of thyroid function. The cause of this variable responsiveness of TSH to TRH in the course of treatment for thyrotoxicosis is conceivable multifarious.

Firstly, it has been shown by Bowers et al. (Bowers et al., 1967) that pituitary responsiveness to TRH is inhibited by thyroid hormones. This inhibition, however, could be overcome by employing an augmented dosage of TRH. In the present study, we failed to elicit positive TRH response using $2,000 \mu \mathrm{g}$ TRH in subjects who did not show a TSH response to a smaller dose of TRH. Secondly, Wilber et al. showed that the inhibition of TRH stimulated TSH release in the presence of normal $\mathrm{T}_{4}$ and $\mathrm{T}_{3}$ levels obtained $48 \mathrm{hr}$ after a single oral administration of thyroid hormone (Wilber et al., 1972). We have found similar results $24 \mathrm{hr}$ after a single intravenous injection of thyroid hormone (Azukizawa and Miyai, unpublished observation). Vagenakis et al. reported recently that there was pituitary unresponsiveness to TRH despite subnormal serum $T_{4}$ and $T_{3}$ concentrations for 2-5 weeks following prolonged suppressive thyroid therapy (Vagenakis et al., 1973). In these three instances, plasma $\mathrm{T}_{4}$ and/or $\mathrm{T}_{3}$ binding proteins did not seem to be altered so as to make their free fractions increase or decrease.

Additionally, two out of 13 subjects in group 2 gave positive TSH response to TRH. On scrutiny, however, their serum $\mathrm{T}_{3}$ was elevated but much less so than the rest of the group. Minimal elevation of serum $\mathrm{T}_{3}$ might 
Case K.N. 39F
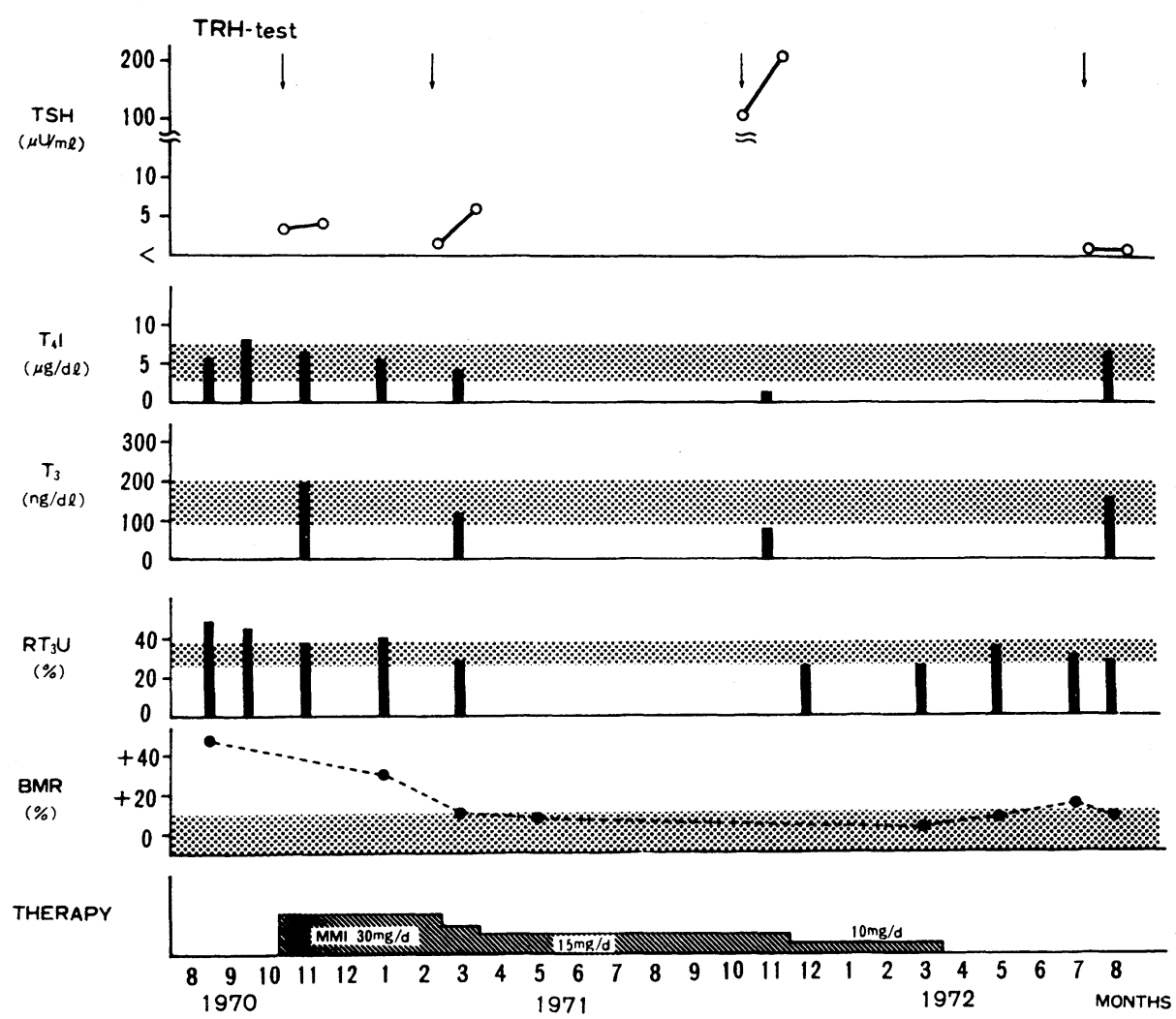

Fig. 1.

Table 4. TSH response to $500 \mu \mathrm{g}$ and $2,000 \mu \mathrm{g}$ TRH administration

\begin{tabular}{|c|c|c|c|c|c|c|c|}
\hline \multirow[b]{2}{*}{ Subjects } & \multirow[b]{2}{*}{ Age } & \multirow[b]{2}{*}{ Sex } & \multirow{2}{*}{$\underset{(\mu \mathrm{g})}{\mathrm{TRH}}$} & \multicolumn{3}{|c|}{ TSH response to TRH } & \multirow[b]{2}{*}{$120 \mathrm{~min}$} \\
\hline & & & & 0 & 30 & 60 & \\
\hline F. I. & 26 & $\mathbf{M}$ & $\begin{array}{r}500 \\
2,000\end{array}$ & $\begin{array}{l}<2 \\
<2\end{array}$ & $\begin{array}{l}<2 \\
<2\end{array}$ & $\begin{array}{l}<2 \\
<2\end{array}$ & $\begin{array}{l}<2 \\
<2\end{array}$ \\
\hline T. O. & 21 & $\mathrm{~F}$ & $\begin{array}{r}500 \\
2,000\end{array}$ & $\begin{array}{l}<1 \\
<1\end{array}$ & $\begin{array}{l}<1 \\
<1\end{array}$ & $\begin{array}{l}<1 \\
<1\end{array}$ & $\begin{array}{l}<1 \\
<1\end{array}$ \\
\hline T. S. & 36 & $\mathbf{M}$ & $\begin{array}{r}500 \\
2,000\end{array}$ & $\begin{array}{l}<1 \\
<1\end{array}$ & $\begin{array}{l}<1 \\
<1\end{array}$ & $\begin{array}{l}<1 \\
<1\end{array}$ & $\begin{array}{l}<1 \\
<1\end{array}$ \\
\hline $\mathrm{Ka} \mathrm{N}$. & 36 & $\mathrm{~F}$ & $\begin{array}{r}500 \\
2,000\end{array}$ & $\begin{array}{l}<1 \\
<1\end{array}$ & $\begin{array}{l}6.8 \\
4.8\end{array}$ & $\begin{array}{l}4.0 \\
3.7\end{array}$ & $\begin{array}{c}<1 \\
1.8\end{array}$ \\
\hline S. Y. & 44 & $\mathrm{~F}$ & $\begin{array}{r}500 \\
2,000\end{array}$ & $\begin{array}{l}7.8 \\
1.1\end{array}$ & $\begin{array}{r}103 \\
58\end{array}$ & $\begin{array}{r}100 \\
82\end{array}$ & $\begin{array}{l}51 \\
88\end{array}$ \\
\hline
\end{tabular}


Case I.I. 39M
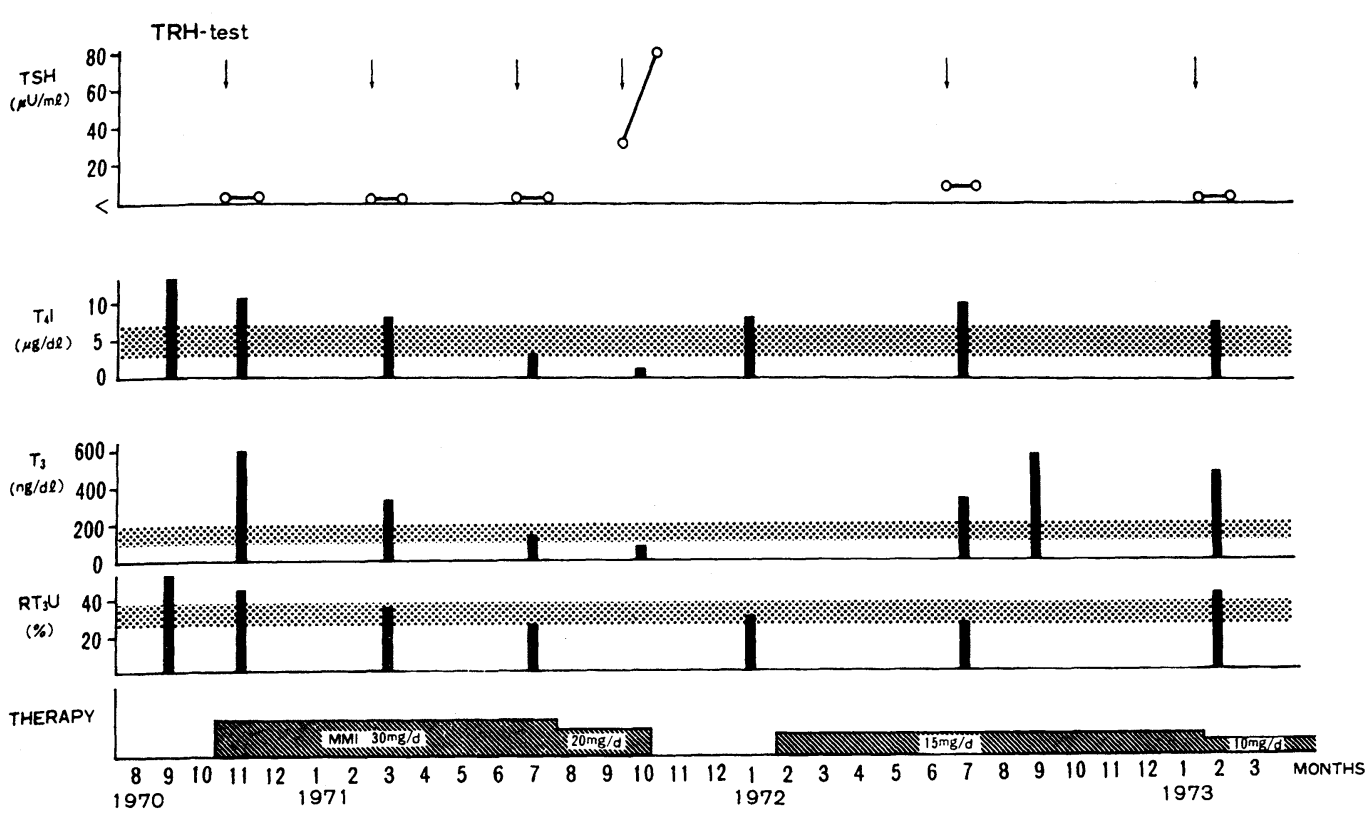

Fig. 2.

Fig. 1 and 2. Results of repeated TRH tests in the course of treatment and relationship with other parameters of thyroid functions (case K. N. and I. I.).

not be sufficient to suppress TSH response to TRH in certain individuals. Three subjects in group 4 with low serum $T_{4}$ and $T_{3}$ failed to respond to TRH. This finding rather suggests that set points of negative feedback regulation of TSH by $T_{3}$ and/or $T_{4}$ vary in individuals. Alternatively, there seem to be a variable time lag between normalization of circulating thyroid hormones and the recovery of responsiveness of pituitary thyrotropic cells to TRH, although the evidence has not been obtained in the present study. Conceivably, a certain amount of time has to elapse before the recovery of TSH resoponsiveness to TRH; during this time the pituitary content of thyroid hormones may become depleted. Kumahara et al. reported reduced TSH content in the pituitary obtained from patients who died of thyrotoxic crisis (Kumahara et al., 1967). These observations suggest that the store of TSH in the pituitary is reduced in the subjects unresponsive to TRH administration. In the present study subjects who did not show TSH response to TRH had always very low baseline serum TSH concentration, i.e., less than $0.5 \mu \mathrm{U} / \mathrm{m} l$, while TRH responders had higher baseline serum TSH.

However, these low basal values of serum TSH concentration cannot be related directly to the reduction of the pituitary TSH content, because Wilber et al. reported transient discrepancy between serum TSH concentration and pituitary TSH content in rats treated with PTU (Wilber and Utiger, 1967).

Lastly, dissociation of thyroid hormones and their secretion rate is a possibility. Woeber et al. demonstrated that serum $\mathrm{T}_{3}$ turnover remained accelerated in 4 subjects who were treated for hyperthyroidism (Woeber et al., 1970). This suggests that the hyperthyroid 
state may be manifested by accelerated turnover of $T_{3}$ in the face of normal serum $T_{4}$ and $T_{3}$ in certain subjects. In such subjects, however, TSH release from the pituitary may be inhibited.

All 10 subjects with low or no TSH response to TRH did not show suppression by $\mathrm{T}_{3}$, whereas all 4 subjects with normal or exaggerated $\mathrm{TSH}$ response to TRH showed normal suppression of function by administered $\mathrm{T}_{3}$. This result is comparable with those of 2 patients studied by Lawton et al. Positive suppression tests appear to require presence of sufficient TSH secretion from the pituitary.

\section{Acknowledgements}

We wish to express our thanks to Mr. Kaichiro Ishibashi, Mrs. Hisako Azukizawa, and Mr. Norio Sawazaki for their technical assistance.

We are very grateful to the National Pituitary Agency, Endocrinology Study Section, National Institute of Arthritis and Metabolic Diseases, U.S.A. for providing human TSH and anti TSH for radioimmunoassay, and to the National Institute for Medical Research, London for standard preparation of TSH.

\section{References}

Braverman. K. E., A. E. Foster and S. H. Ingbar (1968). J. Clin. Invest. 47, 1349.

Bowers, C. Y., A. V. Schally, G. A. Reynolds and W. D. Hawley (1967). Endocrinology 81, 741 .

Chopra, I. J., R. S. Ho and R. Lam (1972). J. Lab. Clin. Med. 80, 729.

Gharib, H., R. J. Ryan, W. E. Mayberry and
T. Hockert (1971). J. Clin. Endocrinol. Metab. 33, 509.

Haigler. E. D. Jr., J. A. Pittman Jr., J. M. Hershman and C. M. Baugh (1971). J. Clin. Endocrinol. Metab. 33, 573.

Hamada, S., T. Nakagawa, T. Mori and K. Torizuka (1970). J. Clin. Endocrinol. Metab. 31, 166.

Hershman, J. M. and J. A. Pittman Jr. (1970). J. Clin. Endocrinol. Metab. 31, 457.

Kumahara, Y., H. Iwatsubo, K. Miyai, H. Masui, M. Fukuchi and H. Abe (1967). J. Clin. Endocrinol. Metab. 27, 333.

Kumahara, Y., K. Miyai and M. Azukizawa (1971). Med. J. Osaka Univ. 22, 97.

Lawton, N. F., R. P. Ekins and J. D. N. Nabarro (1971). Lancet. 2, 14.

Ormston, B. J., R. Barry, R. J. Cryer, G. M. Besser and R. Hall (1971). Lancet. 2, 10.

Patel, Y. C., H. G. Burger and B. Hudson (1971). J. Clin. Endocrinol. Metab. 33, 768.

Redding, T. W. and A. V. Schally (1969). Proc. Soc. Exp. Biol. Med. 131, 420.

Shenkman, L., T. Mitsuma and C. S. Hollander (1973). J. Clin. Invest. 52, 205.

Vagenakis, A., Fi. Azizi, G. Portnay, J. DeRidder, L. Braverman and S. H. Ingbar (1973). Abstract of the 49th Meeting, American Thyroid Association Inc.

Werner, S. C. and M. Spooner (1955). Bull. N. Y. Acad. Med. 31, 137.

Wilber, J. F, A. Jaffer, L. Jacobs, R. D. Utiger and N. Freinkel (1972). Horm. Metab. Res. 4, 508 .

Wilber, J. F. and R. D. Utiger (1967). Endocrinology 81, 145.

Woeber, K. A., R. J. Sobel, S. H. Ingbar and K. Sterling (1970). J. Clin. Invest. 49, 643. 